\title{
Smart specialization as a factor stimulating innovative development of water and wastewater economy
}

\author{
Joanna Machnik-Słomka, \\ ${ }^{1}$ Silesian University of Technology, Faculty of Organization and Management, Poland
}

\begin{abstract}
The article discusses the issue of smart specializations treated as a significant mechanism stimulating innovative development of water and wastewater economy. The article shows the links between the developing of smart specializations and the possibility of development innovative, research and development of the economy. The aim of the article is to present the meaning of the concept of smart specialization in the development of innovative water and wastewater economy at the national level and on the example of the Silesian Region. To achieve the goal, the theoretical assumptions of the concept of smart specialization were also presented. In particular, the article emphasizes the need for cooperation, establishing partnerships for the development of smart specializations that contribute to solving problems and increasing the competitiveness of EU countries and regions.
\end{abstract}

\section{Introduction}

Water and sewage management is a fixed element in development of civilisations and one of the key factors of socioeconomic development affecting the quality of human life [1]. This management has its specific conditions. On the one hand, the entities performing tasks related to water are fully entitled participants of the competitive market, one the other - one must consider the fact that water "is not a commercial product like any other, but rather an inherited good that must be protected, defended and treated as such"[1]. Thus, taking actions requires consideration of intentions and strategic goals relevant not only for the economy, but also for the society and environment [2].

A response to the challenges and issues related to water and sewage management are implemented EU strategic programmes and environmental standards. They are an impulse for development and implementation of innovations in this area [3,4]. Supporting the development of innovative solutions to deal with water challenges uptake brings significant economic opportunities in a rapidly growing world market, in which many European companies are active and where there is strong potential for job creation [5]. Adapting to EU standards and improving the situation in the sector by implementation of innovations and new technologies requires a comprehensive approach and cooperation of various stakeholders at different levels [6]. Although water is predominantly a local issue, water problems are increasingly globalised, requiring focus at a range of scales, from local responses to global strategies [5].

Opposed to these challenges was the strategy implemented at the EU level related to the concept of smart specialization, which is the implementation element of the European innovation policy. The concept of smart specialisation is oriented at achieving and maintaining competitive advantage of EU countries and regions in the global economy owing to the concentration of knowledge and focusing it on a limited number of priority actions [7]. According to the concept, regions and countries that combine innovation with their unique strengths and capabilities of the economy based on the infrastructure and knowledge bases as well as the industry structure have a greater chance of success [7].

Water technologies fall within the range of national, and frequently regional, smart specialisations in Poland. The subject of the article is discussion of the essence and significance of smart specialisations for development of the water and sewage economy. The issue of smart specialisations treated as a significant mechanism stimulating innovative development of water and sewage economy is referred to the analysis at the national and regional level based on the case study regarding the region of Silesia.

\section{The concept of smart specialization and its importance in the innovative development of water and wastewater economy}

The concept of smart specialisation is not completely new. It is but an improvement to the existing structural fund planning methodology. It is based on regional experiences in the area of supporting innovative strategies and on the leading economic thought on the part of leading international institutions, for instance the World Bank, or the OECD [8]. The concept of smart specialization is, however, a generation of innovation

* Corresponding author: joanna.machnik-slomka@polsl.pl 
policy that goes beyond the general creation of innovation potential and traditional investments in research and technology.

The concept of smart specialisations is the outcome of the work of the K4G: Knowledge for Growth Expert Group appointed in 2005. Assumptions regarding the regional specialisation idea, co-authored by, inter alia, D.P. Foray [9], were presented in 2008 in the working documents of the Group as well as in a report containing recommendations regarding the functioning of the European Research Area [10].

The concept was primarily popularised with the Communication from the European Commission titled Europe 2020: A strategy for smart, sustainable and inclusive growth [11]. Smart specialisation remains closely related to one of the three main priorities of the Europe 2020 - Smart development based on knowledge and innovation strategy. It is also a pillar of one of the seven flagship initiatives known under the name of 'Innovation Union', falling within the framework of the Europe 2020 strategy. Creators of smart specialisation name four key principles on which the concept is based (quadruple ' $\mathrm{C}$ '): tough choices and critical mass, competitive advantage, connectivity and clusters, and collaborative leadership [12].

Smart specialisation means identification of unique characteristics and assets of each country and region, highlighting of the competitive advantage of each region, and concentrating regional partners and resources around an accomplishment-oriented vision of their future [8]. It also means strengthening of regional innovation systems, maximising of knowledge transfers, and dissemination of innovation benefits throughout the entire regional economy [8].

In practical terms, of crucial importance was the Guide to Research and Innovation Strategies for Smart Specialisations (RIS3), published in May 2012 and developed with the use of a smart specialisation platform. The Guide contained detailed instructions for regions and Member States with respect to methods of development and implementation of research and innovation strategies for smart specialisations. Development of the 'Research and Innovation Strategies for Smart Specialisations (RIS 3) is designed to allow the use of EU structural funds more efficiently and to increase the synergy between different EU, national and regional policies as well as public and private investments [8]. RIS 3 is a key part of the proposed reform of the EU cohesion policy that supports thematic concentration and strengthens strategic programming and effectiveness [8]. These strategies are supposed to encourage all partners to integrate within a common vision and to develop a creative social capital within the community.

A key premise of the concept of smart specialisation is the application of the ,entrepreneurial discovery process" of new domains of specialization [7] and learning processes. This consists in search for new development areas and opportunities, indication of industries that will set the specific countries and regions for success. Such industries include water and sewage management which is an important area falling within the range of smart specialisations at the European, national and regional level. In this scope, it is important to set proper directions of $\mathrm{R} \& \mathrm{D}$ and innovative works. Introduction of innovations in the scope of, inter alia, water recycling and reuse of water in the water industry can bring multiple benefits for sustainable development [13].

An aspect significant for the purpose of increase the water technology development opportunities is cooperation that must be based on network and cluster relations between the various participants of this process at all the different levels. The process of formation and development of smart specialisations depends on participation and involvement of various entities, inter alia, universities, enterprises, public institutions.

In the field of water economy for supporting innovation, development of smart specializations, innovative partnerships at EU level are visible. The Europe 2020 Flagship Initiative for an Innovation Union proposed the concept of European Innovation Partnerships (EIP). European Innovation Partnerships, aim to speed up innovations that contribute to solving societal challenges, enhance Europe's competitiveness and economic growth. EIPs help to pool expertise and resources by bringing together public and private actors at EU, national and regional level, combining supplyand demand-side measures [5].

One such partnership is the European Innovation Partnership on Water - EIP Water in short. The EIP Water facilitates the development of innovative solutions to address major European and global water challenges. At the same time, the EIP Water supports the creation of market opportunities for these innovations, both inside and outside of Europe. EIP Water focuses furthermore on the following 5 key barriers to innovation in the water sector [5]:

- Access to funding and adequate financial instruments

- Overcoming regulatory barriers

- Promoting best practises in public procurement

- Identifying the role of Public-Public/Public-Private Partnerships

- Promoting testing facilities and dissemination of showcases.

The main objective of EIT Water is to initiate and promote collaborative processes for change and innovation in the water sector across the public and private sector, non-governmental organisations and the general public.

Eight priority areas have been chosen for the EIP Water within its Strategic Implementation Plan (Table 1) [5].

Including five thematic priorities and three cutting priorities. They centre on challenges and opportunities in the water sector, and on innovation driven actions that will deliver the highest impact. Smart technology has been defined as an enabling factor for all priorities [5]. 
Table 1. Eight priority areas have been chosen for the EIP Water

\begin{tabular}{|c|c|c|}
\hline $\begin{array}{l}\text { Five thematic } \\
\text { priorities }\end{array}$ & $\begin{array}{l}3 . \\
4 . \\
5 .\end{array}$ & $\begin{array}{l}\text { Water reuse and recycling } \\
\text { Water and wastewater } \\
\text { treatment, including } \\
\text { recovery } \\
\text { of resources } \\
\text { Water-energy nexus } \\
\text { Flood and drought risk } \\
\text { management } \\
\text { Ecosystem services }\end{array}$ \\
\hline $\begin{array}{l}\text { Three cutting } \\
\text { priorities }\end{array}$ & & $\begin{array}{l}\text { Water governance } \\
\text { Decision support systems } \\
\text { and monitoring } \\
\text { Financing for innovation }\end{array}$ \\
\hline
\end{tabular}

\section{The role of smart specialization in} innovative development of a water and wastewater economy in Poland and the Silesian region

Analysis of strategic documents at the national level shows that one of the key technological areas of great significance for the development of Poland is water and sewage management. It is an important research and development area falling within the National Smart Specialisations (NSS) in Poland.

The national smart specialisations are $R \& D$ and innovative areas with the highest development potential for the Polish economy and society [14]. NSS consists in focusing investments in the areas ensuring increase of the added value and competitiveness of economy on foreign markets which is to contribute to, inter alia, creation of innovative solutions for socioeconomic development as well as support of transformation towards an economy effectively using resources, including natural raw materials [14].

Water and sewage economy, mostly due to such challenges as limited global availability of natural resources, entails the need of application of more effective and sustainable methods of such management. New innovative solutions in water and sewage economy are necessary to, inter alia, guarantee continuity of supply, effective process coordination, water quality improvement, cost reduction. Use of the cutting-edge innovative solutions has become almost inevitable and is an additional challenge for the companies operating in this industry [15-17].

Water and wastewater economy forms part of one of 17 National Intelligent Specializations, i.e. KIS 9 in the thematic area: Natural Resources and Waste Management. Within the KIS 9. „Innovative solutions and technologies in water and wastewater management", the following are distinguished [14]:

1. Improvement of quality of water for consumption and economic purposes.

2. Increase of water resources for consumption and economic purposes.

3. Improvement of surface and ground water quality.
4. Sewage treatment.

5. Recovery of water and other raw materials from the sewage.

6. Use and recovery of energy in the water and sewage management.

Implementation of National Smart Specialization will take place both through the implementation of national programmes (e.g. NCBiR, PARP projects) and with the use of EU funds under the operational programmes [18]. The system for monitoring the National Smart Specialization (NSS) consist of the following elements [18]:

a) IT platform, which will be basis for the monitoring system

b) Steering Committee (SC)

c) Consultative Group (CG)

d) Economic Observatory (EO)

e) Working Groups for national smart specializations (WG)

f) Regional Forum for Smart Specialization (RFSS).

As part of the NSS monitoring system, inter alia a working group was set up in the area of water and wastewater economy. This group is called KIS-12 "Innovative solutions and technologies in water and wastewater management" [19]. It includes representatives of universities, research institutes, enterprises and business support institutions. The Working Group KIS-12 operates on the wide range of topics of quality improvement and increase of water resources, wastewater treatment, water recovery and other raw materials from wastewater, as well as the use and recovery of energy in water and wastewater management [20]. As part of the activities of the KIS-12 group, the issues were divided into three areas: water, sewage and sediments, and municipal engineering.

The essence of the ,entrepreneurial discovery process" is to support bottom-up activities and initiatives that will lead to smart growth and optimal utilization of resources for the development of smart specializations in a given area [18]. Activities implemented at the regional level are of great importance. Water and wastewater economy not only forms a part in the National Smart Specializations, but also often in Regional Smart Specialization. An example of such a region is the Silesian Region. The Silesian Region has the most industrial economy in Poland [21]. Against the state, the Silesian economy has high engagement in research and development (R\&D) activities. The water and sewage industry falls especially within the following Regional Smart Specialisation of the Silesian Voivodship: Green economy. Green economy is a priority area for the Silesian Voivodship due to the highest potential for use in the economy, covering measures supporting economic growth and development, concurrently ensuring availability of natural capital and ecosystem services (green growth), environmental, economic and social policy as well as innovations ensuring effective use of resources in the production and consumption process for the society (green economy) [22]. According to the Report "Global Green New Deal. Policy Brief", one of the key areas of green economy is sustainable use of 
lands, waters and forests. Within the technology groups resulting from the conducted process of entrepreneurial discovery regarding regional smart specialisation "Green Economy", technology groups and subgroups related to the water and sewage economy have been distinguished (Table 2).

Table 2. Selected technology groups resulting from the entrepreneurial discovery process related to water and wastewater economy.

\begin{tabular}{|c|c|}
\hline Technology groups & $\begin{array}{c}\text { Technology subgroups/ } \\
\text { technologies }\end{array}$ \\
\hline $\begin{array}{c}\text { Biotechnologies for } \\
\text { environmental protection }\end{array}$ & Sewage treatment \\
\hline $\begin{array}{c}\text { Civil engineering } \\
\text { technologies }\end{array}$ & $\begin{array}{c}\text { Information materials for } \\
\text { the water and sewage } \\
\text { industry }\end{array}$ \\
\hline $\begin{array}{c}\text { Water processing } \\
\text { treatment and } \\
\text { separation) } \\
\text { technologies, collection } \\
\text { and treatment of water }\end{array}$ & $\begin{array}{c}\text { Sewage treatment } \\
\text { Water treatment } \\
\text { Water and sewage } \\
\text { transport systems } \\
\text { Waste management }\end{array}$ \\
\hline $\begin{array}{c}\text { Environmental } \\
\text { technologies in various } \\
\text { industries }\end{array}$ & Production and supply \\
with water
\end{tabular}

The following types of undertakings are distinguished for the purpose of development of this specialisation [22]:

- Innovative projects, including investments in infrastructure conducted by entities and consortia in the technological areas of the specialisation,

- Support of enterprises, especially the SME sector,

- Support of development of participation of the SME sector companies functioning on the green economy market in the regional and supra-regional cooperation networks,

- Support of intentionally recognised scientific and research competence centres based on co-creation and sharing of the research infrastructure,

- Support of functional and operating competence centres promoting specialisation development,

- Support of scientist - entrepreneur contacts, exchange of experiences among entities, search for and improvement of talents for the benefit of specialisation development,

- Activisation of attitudes and prosumer groups in the green economy.

A particular form of involvement of companies in the „entrepreneurial discovery process" is the activity of clusters, bringing together entrepreneurs and representatives of business environment institutions. Cooperation between various partners based on network and cluster relationships is very important. In this area, the Silesian Water Cluster operates in the Śląskie Voivodeship. The Silesian Water Cluster is a joint initiative of water and sewage management enterprises, local authorities and universities having acommon goal of rational water management [21]. The main goal of the Cluster's activity is mutual co-operation aiming to protect, improve the quality and rationally use the available water recourses of the Silesian Province as well as to co-ordinate activities which promote the reliability and safety of water supply systems' functioning and the implementation of sustainable waste water management ensuring protection of water and land ecosystems [23]. The purpose of the Silesian Water Cluster is to create conditions favouring conduction of water-sewage policy according to the regional Development Strategy "Śląskie 2020" [23]. The technological specialization of the entities belonging to the Silesian Water Cluster focuses on implementing innovative solutions in environmental protection, especially in the scope of water purification and waste water treatment, activated carbon regeneration techniques, waste management of sewage and postcoagulation sediments and using renewable energy sources by water and sewage management companies [21].

Scientific and development institutions in the region have a very important role in the scope of environmental technologies. An example of such an organisation is the Institute for Industrialised Area Ecology in Katowice with its Environmental Technology Verification Department [24]. This Department received accreditation for verification of innovative environmental technologies in the water and sewage economy area according to standard PN-ISO 14034:2018-07. Its introduction should contribute to improvement of reliability of information regarding effects of operation of innovative environmental technologies which may facilitate introduction of new solutions both on the national and foreign markets [24].

\section{Conclusions}

The concept of smart specialization plays an increasingly important role in creating and developing innovations in water and wastewater economy. It is also an important mechanism for the development of innovative business entities. Smart specialisation is of crucial importance to effectiveness of research into and investments in innovation.

Supporting the development of innovative solutions in the field of water-related challenges can bring many economic, social and environmental benefits. The presented analysis indicates the great importance of technologies related to water and wastewater economy, which are an important direction of research and development in the „entrepreneurial discovery process" at the European, national and regional level (an example of the Silesian Region). There is a need to identify factors required to implement the process and to create an effective innovation system that fosters diffusion of innovation. Decisions on smart specializations are the result of in-depth analyzes of endogenous economic advantages and cooperation with socio-economic partners. To a large extent, smart specialisation development possibilities result from the use of partners' research and development capacity. As the results of the analysis show, the water supply industry is in Poland a part of both national smart specializations and regional smart specializations in the Silesian Region.

There is, therefore, a need to seek, establish and develop a strategic partnership between the EU countries 
and regions. To achieve success in the field of smart growth strategy, it is important to convince all stakeholders that this is "a collective social undertaking" based on the assumption that by working together they can accomplish more than by working separately [7]. Such cooperation is based on trust built on partners reliability as well as observance and pursue of moral values [25]. In order to take full advantage of the opportunities related to water innovation in all related sectors, cooperation at regional, national, supranational and EU level is necessary.

\section{References}

1. I. Kłosok-Bazan, Wdrażanie innowacji w gospodarce wodociagowej, (Wydawnictwo Instytutu Badań Systemowych Polskiej Akademii Nauk, Katowice-Warszawa, 2009)

2. I. Kłosok-Bazan, B. Gajdzik, J. Machnik-Słomka, W. Ocieczek, Metalurgija 54, 2 (2015)

3. I. Kłosok-Bazan, Metalurgija 55, (2016)

4. I. Zimoch, Ochr. Sr. 29, 4 (2007) http://www.os.not.pl/docs/czasopismo/2007/Zimoch 4-2007.pdf

5. EIP Water, https://www.eip-water.eu/

6. J. Machnik-Słomka, I. Kłosok-Bazan, Wdrażanie innowacji $w$ gospodarce wodociagowej, (Wydawnictwo Instytutu Badań Systemowych Polskiej Akademii Nauk, Katowice-Warszawa, 2009)

7. Przewodnik Strategii Badań $i$ Innowacji na rzecz inteligentnej specjalizacji (RIS 3), (Luksemburg: Urząd Publikacji Unii Europejskiej, 2012)

8. http://ec.europa.eu/regional_policy/sources/docgene r/informat/2014/smart_specialisation_pl, European Commission

9. P. David, D.P. Foray, B. Hall, Knowledge Economists Policy Brief, 9 (2007)

10. The Role of Community Research Policy in the Knowledge-based Economy, Expert Group Report, European Commission, Belgium (2009)

11. EUROPA 2020. KOM 2010 (2020), European Commission (2010)

12. D. Foray, J. Goddard, X.G. Beldarrain et all., Guide to Research and Innovation Strategies for Smart Specialisations (RIS 3), European Commission (2012)

13. I. Zimoch, J. Szymik-Gralewska, Ecol. Chem. Eng. S 23, 3 (2016)

14. Krajowe Inteligentne Specjalizacje, Ministerstwo Rozwoju (2017)

15. I. Zimoch, E. Szymura, K. Moraczewska-Majkut, Desalin. Water Treat. 57, 3 (2016)

16. I .Zimoch, E. Łobos, Desalin. Water Treat. 52, 19/21 (2014)

https://doi.org/10.1080/19443994.2014.884684
17. M. Bożym, I. Kłosok-Bazan, M. Wzorek, Pol. J. Environ. Stud. 27, 3 (2018)

18. National Smart Specialisation in Poland (2014)

19. http://www.smart.gov.pl/

20. K. Barbusiński, M. Żubrowska-Sudoł, Gaz Woda, 3 (2017)

21. Clusters in the Sląskie Voivodeship, PARP, Warszawa (2011)

22. Model wdrożeniowy Regionalnej Strategii Innowacji Województwa Śląskiego na lata 20132020 wersja 2.0, Katowice (2018)

23. Silesian Water Cluster, https://www.clustercollaboration.eu/clusterorganisations/silesian-water-cluster

24. Przewodnik dla wnioskodawców pilotażowego programu Weryfikacji Technologii Środowiskowych (ETV) Unii Europejskiej. AdvanceETV, Katowice (2012)

25. J. Stachowicz, A. Stachowicz-Stanusch, Org. Zarz. 4 (2011) 